\title{
Antimicrobial and Antidiarrheal Activities of Methanolic Fruit Peel Extract of Pouteria caimito
}

\author{
Abreu $\mathrm{MM}^{1}{ }^{1, *}$, Nobrega P De A ${ }^{2}$, Sales PF${ }^{2}$, Oliveira FRDe ${ }^{3}$, Nascimento AA ${ }^{1}$
}

Abreu $\mathrm{MM}^{1, *}$, Nobrega P De
$\mathrm{A}^{2}$, Sales $\mathrm{PF}^{2}$, Oliveira $\mathrm{FRDe}^{3}$, Nascimento $\mathrm{AA}^{1}$

'Federal University of Amapá, Postgraduate Program in Pharmaceutical Sciences, BRAZIL.

${ }^{2}$ Federal University of Amapá, Postgraduate Program in Health Sciences, BRAZIL.

${ }^{3}$ Pharmaceutical Sciences, Laboratory of Quality Control, Bromatology and

Microbiology, BRAZIL.

\section{Correspondence}

\section{Marina Medeiros De Abreu}

Federal University of Amapá, Postgraduate Program in Pharmaceutical Sciences, BRAZIL.

E-mail: marina_mma@yahoo.com.br

History

- Submission Date: 10-05-2019;

- Review completed: 27-05-2019;

- Accepted Date: 07-06-2019.

DOI : 10.5530/pj.2019.11.150

Article Available online

http://www.phcogj.com/v11/i5

\section{Copyright}

(c) 2019 Phcogj.Com. This is an openaccess article distributed under the terms of the Creative Commons Attribution 4.0 International license.

\begin{abstract}
Introduction: Pouteria caimito is a native Amazonian fruit specie, popularly known as "abiu", that belongs to the Sapotaceae family. It has a wide popular use to relieve diarrhea, cough, fever and inflammation, among other purposes. However, few reports in the scientific literature deal with its phytochemical composition and biological activity. This study aimed to evaluate the antidiarrheal and antimicrobial activity of Pouteria caimito fruit peel extract. Methods: The antidiarrheal activity was evaluated in mice, using modulation models of normal defecation, cathartic agent-induced diarrhea and stimulated intestinal transit. Antimicrobial activity was, in turn, analyzed against strains of gram-positive and gram-negative bacteria (E. coli, S. epidermidis, S. aureus, Klebsiella pneumonie, E. faecalis and Salmonella tiphy) through the determination of the minimum inhibitory concentration (MIC) by the microdilution in broth method. Results: This study showed that there was no antidiarrheal activity in the experimental models analyzed and that the methanolic extract of $P$. caimito (MEPC) can positively modulate normal defecation. Regarding the antimicrobial activity, the crude extract and the ethyl acetate fraction presented a satisfactory action against most of the strains evaluated except for Enterococcus faecalis and Salmonella tiphy. Conclusions: The MEPC did not present any measurable antidiarrheal activity, but more possibly a laxative effect. The extract and acetate fraction showed antimicrobial activity against strains of gram-positive and gram-negative bacteria. The activity of the crude extract was more potent than the results obtained by the use of acetate fractions; the fractions with lower polarity did not present any relevant antimicrobial activity.
\end{abstract}

Key words: Abiu, Antidiarrheal activity, Antimicrobial activity, Sapotaceae.

\section{INTRODUCTION}

Numerous plants used in folk medicine as "antidiarrheal" contain chemical substances that aid in the control of diarrhea associated with increased secretion and intestinal motility due to their astringent, antimicrobial or antiparasitic actions. ${ }^{1-3}$ Inhibition of bacterial growth by a plant extract may be related to the action of secondary metabolites or a group of active compounds, the phytocomplex, present in the plant, which may be responsible for the biological effects of a medicinal plant. ${ }^{4}$

The genus Pouteria (Sapotaceae family) has as its main constituents the triterpenoids and flavonoids ${ }^{5}$, and such compounds have proven antiinflammatory, antiviral, analgesic, cardiovascular, antitumor and anti-HIV ${ }^{6}$ activity, and are also active against gram-positive and gram-negative bacteria, and fungi. ${ }^{7}$ Studies with fruit residues have been growing, demonstrating that nutrients such as phenolic compounds and flavonoids are mainly concentrated in fruit peels and seeds. ${ }^{8}$

The P. caimito species can be found throughout the Amazon, cultivated in farms, orchards and backyards, as well as part of the urban afforestation of some regions in the north of Brazil. 9 The presence of lupeol, $\boldsymbol{\alpha}$-amirin, erythrodiol and Dammarendiol II was revealed in the phytochemical investigation of the fruit benzene extract, and from their peels were isolated: taraxerol, taraxene-3-one and $\beta$-sitosterol. ${ }^{10}$ For the species are attributed several therapeutic uses, evidenced in ethnopharmacological surveys. In particular, its antidiarrheal and anti-dysentery activities, and against other pathologies whose genesis are related to the presence of microorganism. ${ }^{11}$

Due to sanitary and population health issues, researches are continuously carried out with the aim of developing antimicrobials, agents that kills microorganisms or stops their growth, as the main objective to prevent or treat an infection, reducing or eliminating the pathogenic organisms.

Since biological activities for several species of the Sapotacea family and for the Pouteria genus have already been reported, it was important to investigate the fruit of the P. caimito species.

Despite its widespread ethnopharmacological use in the treatment of gastrointestinal disorders, there is no report in the scientific literature of studies validating the action of this $P$. caimito on gastrointestinal motility. The present work describes an investigation of the possible antidiarrheal and antimicrobial properties activities of the methanolic extract of $P$. caimito fruit peels, which is used empirically for this purpose in several areas of the Amapá state, Brazil. The present study shows the modifications produced by the crude extract of the species in the intestinal 
transit, both in normal conditions and in cathartic agent-induced diarrhea.

\section{MATERIAL AND METHODS}

\section{Collection and botanical identification}

The mature fruits of $P$. caimito species were collected in the Municipality of Santana, Amapá, Brazil (latitude: 0³'9.24"S / longitude: 51'9'57.99" $\mathrm{W})$, by the dusk, in the months of april and may, in a residential area, where other different species of plants were also cultivated. After, they were sent to the Animal Experimentation Laboratory (LEA) of the Federal University of Amapá (UNIFAP) and an exsicta was deposited in the Amapaense Herbarium (HAMAB) for specimen identification, under the number 019138 .

\section{Preparation of crude extract}

According to Brazilian Pharmacopoeia, ${ }^{12}$ to obtain the methanolic extract of $P$. caimito (MEPC), the fruit peels $(736 \mathrm{~g})$ were dried in an oven (EL 1.4, Odontobrás, São Paulo, SP, Brazil) at $40^{\circ} \mathrm{C}\left(104^{\circ} \mathrm{F}\right)$ for $72 \mathrm{~h}$ and milled in a knife mill (031, Valinhos, São Paulo, Brazil). The powder obtained $(544 \mathrm{~g})$ was macerated in $3 \mathrm{~L}$ of methanol $\left(\mathrm{CH}_{3} \mathrm{OH}\right)$, under stirring, every $24 \mathrm{~h}$ for 7 days. The resulting extractive solution was filtered and concentrated in a rotary evaporator (FST 801, Fisatom, São Paulo, Brazil) at a temperature of $40^{\circ} \mathrm{C}\left(104^{\circ} \mathrm{F}\right)$ until obtaining a pasty extract. ${ }^{13}$

\section{Obtaining the fractions (partition: liquid-liquid)}

From the crude extract, the liquid-liquid partition was performed, using a system of solvents in increasing order of polarity. Initially the crude extract was resuspended in methanol/water (4:6) solution, then the serial partition was performed with $200 \mathrm{~mL}$ of the following solvents: n-hexane $\left(\mathrm{C}_{6} \mathrm{H}_{14}\right)$, chloroform $\left(\mathrm{CHCl}_{3}\right)$ and ethyl acetate $\left(\mathrm{C}_{4} \mathrm{H}_{8} \mathrm{O}_{2}\right)$, respectively. Subsequently, all fractions obtained were concentrated on a rotary evaporator and the final product was weighed for yield calculation. To calculate the yield, the following formula was used. ${ }^{14}$

Yield $=\frac{\text { weight of the fraction }(\mathrm{g})}{\text { weight of extract }(\mathrm{g})} \times 100 \%$

\section{Animals}

Male Swiss albino mice (Mus musculus), from the Laboratory of Animal Experimentation of UNIFAP, weighing between 25 and $35 \mathrm{~g}$, were used for antidiarrheal activity assays. The animals were kept under controlled temperature conditions $\left(25^{\circ} \mathrm{C} / 77^{\circ} \mathrm{F}\right)$ and a light-dark cycle of $12 \mathrm{~h}$ (6:00 a.m. - 6 p.m.), with free access to feed and water.

\section{Evaluation of antidiarrheal activity}

For each experimental protocol (modulation of normal defecation, cathartic agent-induced diarrhea and stimulated intestinal transit) five groups of five animals $(n=5)$ were used, to which were administered, respectively: positive control (loperamide $5 \mathrm{mg} / \mathrm{kg}$ ), vehicle $(5 \%$ Tween 80) and MEPC at doses of $30 \mathrm{mg} / \mathrm{kg}, 100 \mathrm{mg} / \mathrm{kg}$ and $300 \mathrm{mg} / \mathrm{kg}$, following the study proposed by Medeiros, ${ }^{16}$ with modifications.

Before each experiment, the animals were submitted to an $18 \mathrm{~h}$ fasting with free access to water. They were placed separately in appropriate cages, with metal grating at the bottom to avoid coprophagy, as well as the ingestion of wood shavings. ${ }^{15}$

\section{Modulation of normal defecation in mice}

After the fasting period, each group of animals received their respective treatments: positive control (loperamide $5 \mathrm{mg} / \mathrm{kg}$ ), the control (vehicle: $5 \%$ Tween 80 ) and MEPC at doses of $30 \mathrm{mg} / \mathrm{kg}, 100 \mathrm{mg} / \mathrm{kg}$ and 300 $\mathrm{mg} / \mathrm{kg}$. Subsequently, they were then placed in individual cages with filter paper at the bottom for feces visualization and after one hour of administration, the total number of feces was counted for each individual animal, every hour, up to four hours. The total number of feces excreted per group was registered and compared with the groups receiving the extract and the control groups. ${ }^{16}$

\section{Cathartic agent-induced diarrhea in mice}

Following the model of Izzo et al. ${ }^{17}$ and Galvez et.al ${ }^{15}$, with modifications, diarrhea was induced by oral administration of castor oil $(0.3 \mathrm{~mL} /$ animal $)$. After 30 minutes the treatments were administered: loperamide $\left(5 \mathrm{mg} / \mathrm{kg}\right.$ ), vehicle (Tween $80^{\circ}$ a $5 \%$ ), MEPC $30 \mathrm{mg} / \mathrm{kg}$, $100 \mathrm{mg} / \mathrm{kg}$ e $300 \mathrm{mg} / \mathrm{kg}$. The animals were then placed in individual polyethylene cages, with filter paper in the bottom (changed every hour). The severity of diarrhea was evaluated for four hours on an arbitrary scale, and a score was assigned to each animal, taking into account the consistency of the feces present in each paper, as follows: 0 $=$ no feces; $1=$ normal feces; $2=$ diarrheal (soft or aqueous feces). The number of normal and diarrheal feces were noted and compared to the respective control groups counts.

\section{Stimulated intestinal transit in mice}

The respective groups of animals were initially treated with the extract (MEPC 30, 100 and $300 \mathrm{mg} / \mathrm{kg}$ ), loperamide $(5 \mathrm{mg} / \mathrm{kg}$ ) and the vehicle. After 60 minutes, castor oil ( $0.3 \mathrm{~mL} /$ animal, v.o) was administered and, after another 60 minutes, a suspension of activated charcoal $(5.0 \%)$ in Agar (1.5\%) was also administered $(0.3 \mathrm{~mL} /$ animal, v.o) to the animals. They were euthanized 40 minutes after administration of the activated Agar-charcoal suspension, having their intestines dissected to verify the distance covered by the marker suspension. The total length of the small intestine and the length of the distance covered by the marker suspension were measured. ${ }^{18}$ The results were expressed as a percentage of the distance covered by the suspension in function of the total length of the small intestine, calculated by the formula below ${ }^{19}$ :

$\%$ intestinal transit $=\frac{\text { distance traveled by charcoal }}{\text { total small intestine lenght }} \times 100 \%$

Antimicrobial activity of the extract and fractions

\section{Microorganisms and culture medium}

Bacteria were obtained from the National Institutes of Health Quality Control (INCQS)/ Oswaldo Cruz Foundation (FIOCRUZ), three grampositive strains: Staphylococcus aureus (ATCC 6538), Staphylococcus epidermidis (ATCC 12228) and Enterococcus faecalis (ATCC 9083); and three gram-negative strains: Escherichia coli (ATCC 8789), Klebisiela pseudomonas (ATCC 4382), Salmonella typhi (ATCC 259). They were kept at the Quality Control, Bromatology and Microbiology Laboratory of UNIFAP, on nutrient agar. The culture medium used in the microbiological assays were Müller-Hinton Agar $\left(\mathrm{Merck}^{\circledR}\right)$, prepared and used according to the manufacturer's instructions.

\section{Bacterial inoculum}

The bacterial inoculum of the used strains was obtained from 24 $\mathrm{h}$ culture at $35^{\circ} \mathrm{C}\left(95^{\circ} \mathrm{F}\right)$ and the suspensions prepared in test tubes $(16 \times 16 \mathrm{~mm})$ containing $10 \mathrm{~mL}$ of sterile saline $(\mathrm{NaCl} 0.9 \%)$. Then, these suspensions were shaken for two minutes with the aid of Vortex apparatus, the turbidity being compared and adjusted to that presented by the 0.5 standard of McFarland scale, equivalent to $10^{8} \mathrm{CFU} / \mathrm{mL}^{20,21,22}$. The bacterial suspensions were diluted $1: 9 \mathrm{v} / \mathrm{v}$ in saline solution to obtain a final inoculum containing, approximately, $10^{3} \mathrm{CFU} / \mathrm{mL}$ as described by the Clinical and Laboratory Standards Institute. ${ }^{23}$ 


\section{Minimal Inhibitory Concentration (MIC) and Minimal Bactericidal Concentration (MBC)}

The MIC and MBC assays were performed using the method of microdilution in broth, in the Mueller-Hinton broth, as described by the Clinical and Laboratory Standards Institute. ${ }^{23}$

For the microdilution test, $100 \mu \mathrm{l}$ of the nutrient broth and then 100 $\mu \mathrm{l}$ of the natural product (crude extract, hexane fraction, chloroform fraction and ethyl acetate fraction) were added to each of the 96 wells of the plate, at the initial concentration of $5 \mathrm{mg} / \mathrm{mL}$. Serial dilution at the ratio of 2 was performed $(5 \mathrm{mg} / \mathrm{mL}$ to $0.16 \mathrm{mg} / \mathrm{mL})$ for the extract and fractions. After the dilutions, $100 \mu \mathrm{l}$ of the inoculum suspensions were inoculated into all wells. The plate was incubated at $35^{\circ} \mathrm{C}\left(95^{\circ} \mathrm{F}\right)$ for $24 \mathrm{~h}$ and cloraphenicol $(50 \mu \mathrm{g} / \mathrm{mL})$ was used as a positive control. Control of the culture medium and the negative control (vehicle) were also performed.

In order to determine the MIC of extract and fractions against the bacterial species tested, a solution of resazurin sodium in sterilized distilled water $(0.01 \% \mathrm{w} / \mathrm{v})$ was used. After the incubation period, 20 $\mu \mathrm{L}$ of this indicator solution was dispensed into each well, and then incubated again for $3 \mathrm{~h}$ at $35^{\circ} \mathrm{C}\left(95^{\circ} \mathrm{F}\right)$ in an oven. The interpretation of the result related to MIC was seen more securely, defined as the lower concentration of the natural product capable of inhibiting bacterial growth, evidenced by the blue color of the indicator used, where the change from blue to pink indicate reduction of resazurin by growth of bacterial strains. ${ }^{24}$

To determine $\mathrm{MBC}, 10 \mu \mathrm{L}$ of the contents of each well showing bacterial growth were seed and incubated on Mueller-Hinton agar at $37{ }^{\circ} \mathrm{C}$ $\left(98.6^{\circ} \mathrm{F}\right)$ for $24 \mathrm{~h}$. The $\mathrm{MBC}$ was defined as the lowest concentration of extracts or fractions that resulted in no growth or less than three colonies ( $99.9 \%$ death), as described by Quadros et al. ${ }^{25}$

\section{Statistical analysis}

Results were expressed as mean \pm standard error of the mean (s.e.m.) and analyzed using one-way variance analysis (one-way ANOVA / ANOVA) followed by the Tukey's test. The software used was GraphPad Prism, version 5.0 (GraphPad Software, San Diego, CA, U.S.A.). The level of significance was set at $p<0.05$.

\section{Ethical and legal aspects}

All the experimental protocols were duly appreciated by the Ethics Committee on the Use of Animals (CEUA) of the Federal University of Amapá (UNIFAP) receiving approval number 0017/2016.

\section{RESULTS}

\section{Yield of crude extract and fractions}

After concentration of the methanolic extract of the fruit peel $P$. caimito (MEPC), the hexane (FH), chloroform (FC) and ethyl acetate (FA) fractions, the percent yields were: $9.00 \%, 3.58,1.74 \%$ and $0.80 \%$, respectively.

\section{Evaluation of MEPC on modulation of normal defecation}

Regarding the effect of MEPC on modulation of normal defecation in mice, it was evidenced that, $4 \mathrm{~h}$ after the treatments, the increasing doses of the extract $(30 \mathrm{mg} / \mathrm{kg}, 100 \mathrm{mg} / \mathrm{kg}, 300 \mathrm{mg} / \mathrm{kg})$ induced a mean evacuation of $0.35 \pm 0.18,2.7 \pm 0.67$ and $0.4 \pm 0.08$, respectively. These effects were different in relation to those observed in the negative control group (vehicle) and positive control group (loperamide $5 \mathrm{mg} /$ $\mathrm{kg}$ ), both with mean evacuation of $0.01 \pm 0.07$ (Table 1 ).

The number of evacuations throughout the $4 \mathrm{~h}$ after the treatment with MEPC at the dose of $100 \mathrm{mg} / \mathrm{kg}$ was significantly higher when compared to the other doses $(300 \mathrm{mg} / \mathrm{kg}$ and $30 \mathrm{mg} / \mathrm{kg}$ ) and to the vehicle. In all groups, except for the one which received extract at the dose of $100 \mathrm{mg} /$ $\mathrm{kg}$, it's observed that the values of evacuations reach zero at the end of $4 \mathrm{~h}$. The positive control group (loperamide) had the results expected.

Evaluation of the effects of MEPC on cathartic agentinduced diarrhea in mice

The total evacuation means of the extract at doses of 30, 100 and $300 \mathrm{mg} / \mathrm{kg}$ were $1.4 \pm 0.45,1.05 \pm 0.32$ and $0.65 \pm 0.29$, respectively. Compared to vehicle group $(1.65 \pm 0.60)$, therefore, even though the mean evacuation were dose-proportionally inhibited, this effect is not statistically significant (Figure 1).

When compared to the vehicle group, the diarrheal evacuations of the extract groups also did not present significant difference between the means (Figure 1).

\section{Effect of MEPC on stimulated intestinal transit in mice}

Oral administration of the extract at the doses tested $(30,100$ and 300 $\mathrm{mg} / \mathrm{kg}$ ) did not show a significant reduction of the distance covered by the marker suspension when compared to the vehicle group, suggesting that the extract did not interfere in the intestinal transit (Figure 2). The mean inhibition was $74,66 \% \pm 8,72 \% \pm 8,62$ e $77,30 \% \pm 6,2$ for the MEPC (dose $30 \mathrm{mg} / \mathrm{kg}, 100 \mathrm{mg} / \mathrm{kg}$ and $300 \mathrm{mg} / \mathrm{kg}$, respectively), demonstrating no significant difference between means.

\section{Evaluation of the antimicrobial activity of the extract and fractions}

With regard to antimicrobial activity, it can be observed in Table 2 that the crude extract was more effective against the strains of S. epidermidis and E. coli, with MIC of $0.6 \mathrm{mg} / \mathrm{mL}$ for both strains. The crude extract also presented relevant MIC values for the strains of $S$. aureus $(1.2 \mathrm{mg} /$ $\mathrm{mL}$ ) and K. pneumonie $(1.2 \mathrm{mg} / \mathrm{mL}$ ). Considering the fractions (hexane, chloroform and ethyl acetate), the ethyl acetate fraction presented better results, with MIC of $2.5 \mathrm{mg} / \mathrm{mL}$ for $S$. aureus and $1.2 \mathrm{mg} / \mathrm{mL}$ for S. epidermidis, E. coli and K. pneumoniae. The hexane and chloroform fractions presented MIC above $5 \mathrm{mg} \mathrm{mL}$ for $S$. aureus, S. epidermidis, $E$. coli and K. pneumonia strains. There was no antimicrobial activity against strains of E. faecalis and S. tiphy.

Table 1: Mean of 4-hour evacuations of MEPC-treated groups at 30, 100 and $300 \mathrm{mg} / \mathrm{kg}$ and control groups.

\begin{tabular}{|c|c|c|c|c|c|}
\hline Treatment & $1^{\text {a hour }}$ & $2^{\text {a hour }}$ & $3^{\text {a hour }}$ & $4^{\mathrm{a}}$ hour & Mean \pm e.p.m of $4 h$ \\
\hline Loperamide & $0.4 \pm 0.24$ & 0 & 0 & 0 & $0.01 \pm 0.07$ \\
\hline Vehicle & 0 & $0.4 \pm 0.24$ & 0 & 0 & $0.01 \pm 0.07$ \\
\hline MEPC 30 mg/kg & $1.4 \pm 0.5$ & 0 & 0 & 0 & $0.35 \pm 0.18$ \\
\hline MEPC $100 \mathrm{mg} / \mathrm{kg}$ & $4.6 \pm 1.54$ & $4.6 \pm 1.43$ & $1 \pm 0.55$ & $0.6 \pm 0.6$ & $2.7 \pm 0.67^{*}$ \\
\hline MEPC $300 \mathrm{mg} / \mathrm{kg}$ & $1.2 \pm 0.58$ & $0.4 \pm 0.25$ & 0 & 0 & $0.4 \pm 0.08$ \\
\hline
\end{tabular}

${ }^{*} p<0.05$ vs loperamide, vehicle, MEPC $30 \mathrm{mg} / \mathrm{kg}$ e $300 \mathrm{mg} / \mathrm{kg}$ 


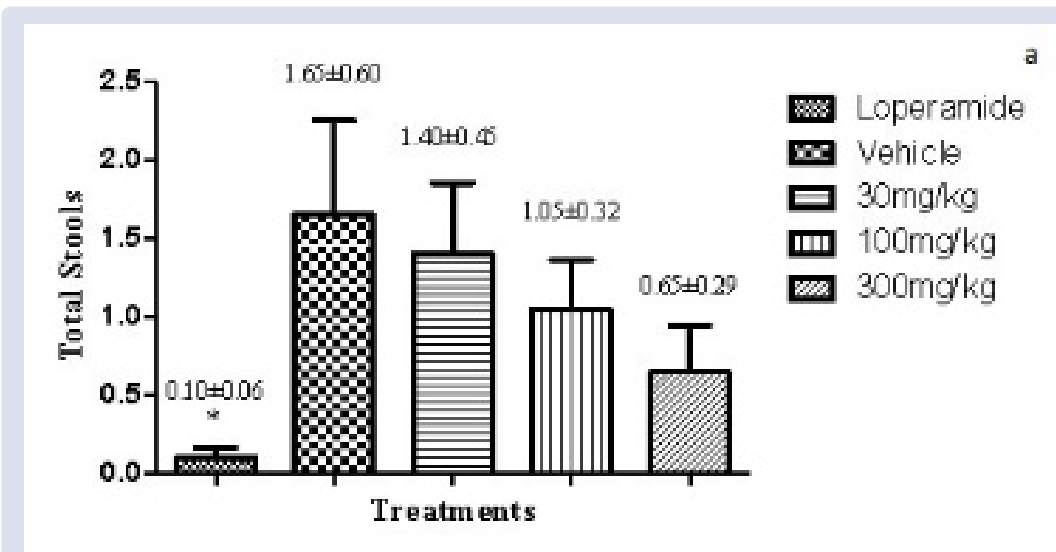

Figure 1: Effect of different doses of MEPC $(30,100$ and $300 \mathrm{mg} / \mathrm{kg})$, vehicle and loperamide on diarrhea induced by castor oil. In (A) total stools and (B) diarrheal stools.

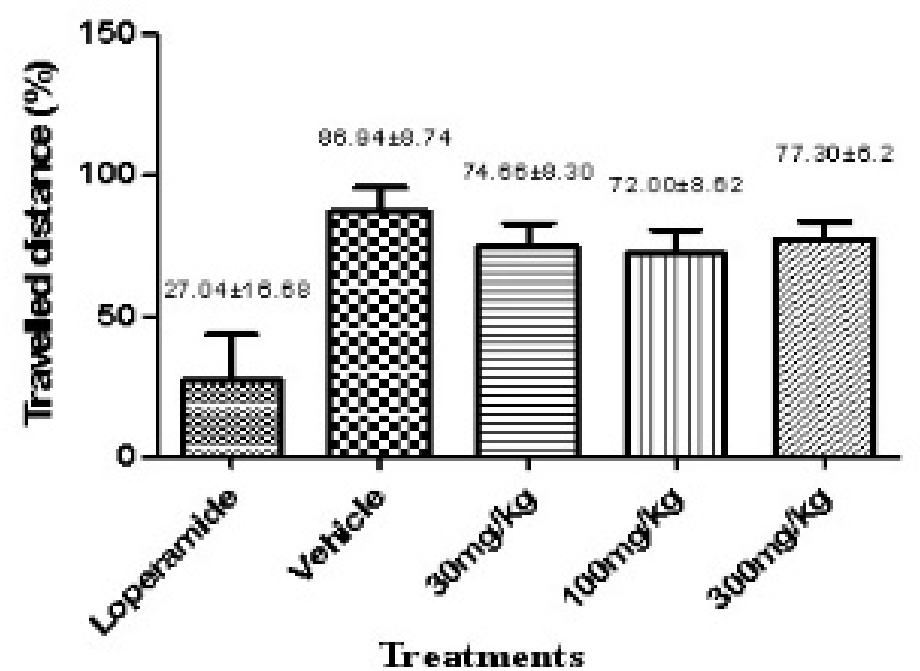

Figure 2: Effect of MEPC (30 mg/kg, $100 \mathrm{mg} / \mathrm{kg}$ and $300 \mathrm{mg} / \mathrm{kg}, \mathrm{n}=5)$, vehicle and loperamide $(5 \mathrm{mg} / \mathrm{kg}$ ) on stimulated intestinal transit.

Table 2: Minimal Inhibitory Concentration (MIC) and Minimal Bactericidal Concentration (MBC) of $P$. caimito extract and fractions against gram positive and negative bacteria.

\begin{tabular}{|c|c|c|c|c|c|c|c|c|}
\hline \multirow{2}{*}{ BACTERIA } & \multicolumn{2}{|c|}{ CE } & \multicolumn{2}{|c|}{ HF } & \multicolumn{2}{|c|}{$\mathrm{AF}$} & \multicolumn{2}{|c|}{ CF } \\
\hline & CIM & CBM & CIM & CBM & CIM & CBM & CIM & CBM \\
\hline Staphylococcus aureus & 1.2 & $>5$ & $>5$ & $>5$ & 2.5 & $>5$ & $>5$ & $>5$ \\
\hline Enterococcus faecalis & - & - & - & - & - & - & - & - \\
\hline Escherichia coli & 0.6 & $>5$ & $>5$ & $>5$ & 1.2 & 2.5 & $>5$ & $>5$ \\
\hline
\end{tabular}

$\mathrm{CE}=$ crude extract $\mathrm{HF}=$ hexane fraction; $\mathrm{AF}=$ acetate fraction; $\mathrm{CF}=$ chloroform fraction

\section{DISCUSSION}

Many plant compounds, such as the triterpenes and flavonoids found in the genus Pouteria ${ }^{5}$, are responsible for proven biological activities, such as antimicrobial, fungicidal, anti-inflammatory and antioxidant. ${ }^{26-28}$ Plants used in folk medicine as antidiarrheal have in their composition chemicals with astringent, antimicrobial or antiparasitic actions, helping to control diarrhea, in addition to reducing intestinal transit and increasing water absorption. ${ }^{29}$
Others researches, with similar methodology used in the present study, have demonstrated the potential antidiarrheal activity of plant extracts (Psidium guajava, Stachytarpheta cayenensis, Polygonum punctatum, Eugenia uniflora, Aster squamatus, Byrsonima cinera and Cymbopogon (itratus $)^{29-32}$ and according to a study by Di Carlo et al. ${ }^{33}$, plants with flavonoids present an inhibitory activity on the intestinal transit of mice and inhibit the water and sodium secretion stimulated by castor oil in rats. In addition, plants that contain tannins in their composition may have an antidiarrheal effect. ${ }^{29}$ 
Considering its popular use and assuming that terpenes, phenols and flavonoids, reported for Pouteria genus e P. caimito species, could contribute to a possible antidiarrheal activity of this plant, we investigated whether the extract of the fruit peels would have an influence on normal defecation, stimulated diarrhea and intestinal transit. However, the extract was not able to significantly inhibit these responses in mice, as demonstrated in the studies above. The MEPC, had, instead, a positive modulation effect on this parameter, but it was not possible to determine the reason in the present study.

The presence of certain phytochemicals constituents in plants can be influenced by some factors such as season, time of harvesting, handling and packaging of the plant, or degradation of constituents by environmental factors. ${ }^{34}$ That may be one of the reasons why the studied species do not demonstrate the activity expected.

Assuming that diarrhea may be infectious, antimicrobial drugs could be used on the treatment, but as a result of the generalized resistance of these pathogens to medication, pharmacotherapeutic possibilities have become increasingly restricted. ${ }^{35}$ Then, due to the presence of several studies with the Pouteria genus and aiming to investigate the antidiarrheal effect attributed to the species under study, we attempted to identify the Minimal Inhibitory Concentration (MIC) and Minimal Bactericidal Concentration (MBC) against the bacterial species tested.

Others species of Pouteria genus showed action against bacterial strains, including those tested in this study. The species $P$. venos $a^{36}, P . \operatorname{torta}^{37,38}$, $P$. pallida and $P$. gardnerii ${ }^{39,40}$ showed activity against $S$. aureus. The $P$. venos $a^{36}$ has an effect on $S$. epidermidis, and $P$. torta $^{37}$, P. ramiflora, $P$. glomerata, $P$. psamophila and P. grandiflor ${ }^{41}$ had antimicrobial action for E. coli. A recent study showed that strains of Klebsiella pneumoniae were the target of the inhibitory action of the P. caimito leaf extract. ${ }^{42}$ There were no studies, to our knowledge, demonstrating the action of the genus on Enterococcus faecalis and Salmonella tiphy.

In the present study, both the crude extract and the ethyl acetate fraction showed action against gram-positive bacteria ( $S$. aureus and S. epidermidis), and gram-negative (E. coli and K. pneumoniae), being the activity of the crude extract more potent. However, there was no action of MEPC and fractions against strains of Enterococcus faecalis and Salmonella tiphy, such data corroborating with the literature data for the genus. According to Fabry et al ${ }^{43}$, for an extract to be considered as potentially useful in therapeutics, the MIC value should be lower than $8 \mathrm{mg} / \mathrm{mL}$ and in the evaluation of the antimicrobial activity of $P$. caimito, as the results were better for the crude extract and then for ethyl acetate fraction, the results obtained in this study suggest that the active compounds have more polar characteristics, since the hexane and chloroform fractions were not efficient. Moreover, the antimicrobial effect may be due to the synergism of substances that, when fractionated, tend to decrease efficacy.

\section{CONCLUSIONS}

In view of the obtained results, we can conclude that the methanolic extract of $P$. caimito (MEPC), at the doses tested, did not present direct antidiarrheal activity on the gastrointestinal tract, either altering the normal defecation frequency, inhibiting induced diarrhea or stimulated intestinal transit. However, MEPC and the acetate fraction showed antimicrobial activity against strains of Gram-positive and Gramnegative bacteria. The activity of the extract was the most potent and the fractions with less polarity did not present any relevant activity.

\section{ACKNOWLEDGEMENTS}

We would like to thank the Laboratory of Quality Control, Bromatology and Microbiology of the Federal University of Amapá. We also thank the professor Carlos Henrique Medeiros de Abreu from the State University of Amapá, for his collaboration in the statistical analyses.

\section{REFERENCES}

1. Almeida CE, Karnikowski MGO, Foleto R, Baldisserotto B. Analysis of the antidiarrhoeic effect of plants used in popular medicine. Rev Saúde Públ 1995;29(6):428-33

2. Caceres A, Cano O, Samayoa B, Aguilar L. Plants used in Guatemala for the treatment of gastrointestinal disorders. Screening of 84 plants against enterobacteria. J Ethnopharmacol. 1990;30(1):55-73.

3. Silva SL, Nascimento AA, Ribeiro EFB, Ribeiro RB, Alves CM, Santos AM, Burmann APR, Mira Neto RDA. Avaliação da toxicidade aguda pré-clínica do extrato metanólico das cascas do caule de Parahancornia amapa (Apocynaceae). Acta Amaz. 2016;46(1):73-80

4. ANVISA 2010. Resolução $n^{\circ} 14$ de 31 de março de 2010. Diário Oficial da União. [updated 2010 Apr 30; cited 2018 Jan 27]. Available from: www diariodasleis.com.br/busca/exibelink. php?numlink $=213878$

5. Silva CAM, Simeoni LA, Silveira D. Genus Pouteria : Chemistry and biological activity. Rev bras farmacogn. 2009;19(2A):501-9.

6. Patočka J. Biologically active pentacyclic triterpenes and their current medicine Signification. J Appl Biomed. 2013;1(1):7-12

7. Trombetta D, Castelli F, Sarpietro MG, Venuti V, Cristani M, Daniele C, et al Mechanisms of antibacterial action of three monoterpenes. Antimicrob Agents of Chemother. 2005;49(6):2474-8.

8. Butler MS, Buss AD. Natural products-the future scaffolds for novel antibiotics? Biochem Pharmacol. 2006;71(7):919-29.

9. Rodrigues LA. Contribuição ao estudo bioquímico de frutas tropicais e exóticas produzidas no Brasil: pectina, açúcar e proteína. Dissertação, Instituto de Química, Universidade Estadual Paulista, Araraquara, São Paulo; 2009, p 4-55.

10. Ardon A, Nakano T. Triterpenes from the bark of Pouteria caimito. Planta med 1973;23(4):348-52

11. Vásquez SPF, Mendonça MD, Noda SDN. Etnobotânica de plantas medicinais em comunidades ribeirinhas do Município de Manacapuru, Amazonas, Brasil. Acta Amaz. 2014;44(4):457-72.

12. Anvisa. Agencia Nacional de Vigilância Sanitária. Farmacopeia Brasileira, volume 1. $5^{\mathrm{a}} \mathrm{Ed}$. Brasilia,2010b. Available from: http://portal.anvisa.gov.br/documents/3 3832/260079/5\%C2\%AA+edi\% C3\%A7\% C3\%A3o+-+Volume+1/4c530f86fe83-4c4a-b907-6a96b5c2d2fc

13. Schenkel EP, Gosmann G, Petrovick PR. Produtos de origem vegetal e o desenvolvimento de medicamentos. In: SIMÕES CMO et alii. Farmacognosia: da planta ao medicamento. Florianópolis e Porto Alegre: Editoras da UFSC e UFRGS, 1999.

14. Rodrigues TS, Guimarães SF, Rodrigues-das-Dôres RG, Gabriel JV. Métodos de secagem e rendimento dos extratos de folhas de Plectranthus barbatus (boldoda-terra) e P. ornatus (boldo-miúdo). Rev Bras Plantas Med. 2011;13:587-90.

15. Galvez J, Zarzuelo A, Crespo ME. Antidiarrhoeic activity of Euphorbia hirta extract and isolation of an active flavonoid. Planta med. 1993;59(4):333-6.

16. Medeiros FA de. Estudo fitoquímico e biológico de espécies amazônicas: Pradosia huberi (Ducke) Ducke (Sapotaceae) e Licania macrophylla Bent. (Chrysobalanaceae). Tese (Doutorado em Produtos Naturais e Sintéticos Bioativos) - Universidade Federal da Paraíba, João Pessoa, 2008.

17. Izzo AA, Nicoletti M, Giannattasio B, Capasso F. Antidiarrhoeal activity of Terminalia sericea Burch ex. DC extracts. (EMSI). In: Capasso, F.; Mascolo, N. (Eds). Natural drugs and the digestive tract, Roma, p. 223-230.

18. Visher P, Casals-Stenzel J. Influence of prostacyclin and indomethacin on castor oil induced gastrointestinal effects in rats. J Pharm Pharmacol. 1993;35(3):1526.

19. Wong $\mathrm{Cl}$, Wai MK. Effects of aspirin and paracetamol on naloxone reversa of orphine-induced inhibition of gastrointestinal propulsion in mice. Eur $\mathrm{J}$ Pharmacol. 1981;73(1):11-9

20. NCCLS. 2004. Performance standards for antimicrobial disk susceptibility testing. Fourteenth informational supplement. NCCLS document M100-514. NCCLS, Wayne, Pa.

21. Hadacek F, Greger $H$. Testing of antifungal natural products: methodologies, comparability of results and assay choice. Phytochem Anal. 2000;11(3):137-47.

22. Cleeland $R$, Squires $E$. Evaluation of new antimicrobials in vitro and in experimental animal infections. In: Lorian, V. M. D., (Williams \& Wilkins) Antibiotics in Laboratory Medicine., Baltimore, Maryland, 1991 p. 739-789.

23. CLSI. (2012). Methods for dilution antimicrobial susceptibility tests for bacteria that grow aerobically; Approved Standard-Ninth Edition. Clinical and Laboratory Standards Institute (CLSI) document M07-A9 [ISBN 1-56238-783-9] USA.

24. Mann CM, Markham JL. A new method for determining the minimum inhibitory concentration of essential oils. J Appl Microbiol. 1998;84(4):538-44.

25. Quadros AU, Bini D, Pereira PT, Morone EG, Monteiro MC. Antifungal activity of some cyclooxygenase inhibitors on Candida albicans: PGE2-dependent mechanism. Folia Microbiol (Praha). 2011;56(4):349-52. 
26. Oliveira AKM, Rizzi ES, Pereira KCL, Bono JAM, Pina JC, Matias R. Phytochemical analysis and fungicide potential of Pouteria ramiflora against Lasiodiplodia theobromae. Horti Bras. 2017;35(4):564-70.

27. Okoba D. Atividade Antimicrobiana dos Extratos Hidroalcóolicos de Frutos do Pantanal: Byrsonima cydoniifolia A. Juss. (Canjiqueira), Pouteria glomerata (Miq.) Radlk. (Laranjinha de pacu) e Vitex cymosa Bert. (Tarumã). Dissertação (Mestrado Saúde e Desenvolvimento), Universidade Federal do Mato Grosso do Sul, Campo Grande, Mato Grosso do Sul. 2016, 66p.

28. Barreiros ALBS, Barreiros ML. Atividade antioxidante das frutas amazônicas abiu (Pouteria caimito), biribá (Rollinia mucosa) e cubiu (Solanum sessiliflorum) pelo método do seqüestro do DPPH. In: 34 Reunião Anual da Sociedade Brasileira de Química, Florianópolis- SC. Laboratório de Produtos Naturais Departamento de Química - Universidade Federal de Sergipe, 2011

29. Almeida CE, Karnikowski MGO, Foleto $R$, Baldisserotto B. Analysis of antidiarrhoeic effect of plants used in popular medicine. Revista de Saúde Pública. 1995;29(6):428-33.

30. Caceres A, Cano O, Samayoa B, Aguilar L. Plants used in Guatemala for the treatment of gastrointestinal disorders. 1. Screening of 84 plants against enterobacteria. Journal of Ethnopharmacology. 1990;30(1):55-73.

31. Figueiredo ME, Michelin DC, Sannomiya M, Silva MA, Santos LC, Almeida LFR, et al. Avaliação química e da atividade antidiarréica das folhas de Byrsonima cinera DC. (Malpighiaceae). Brazilian Journal of Pharmaceutical Sciences. 2005;41(1):79-83.

32. Tangpu V, Yadav AK. Antidiarrhoeal activity of Cymbopogon citratus and its main constituent, citral. Pharmacologyonline. 2006;290-298.

33. Di Carlo G. Inhibition of intestinal motility and secretion by flavonoids in mice and rats: structure-activity relationships. Journal of Pharmacy and Pharmacology. 1993;45(12):1054-9.

34. Folashade O, Henry O, Peter O. Standardization of herbal medicines-A review. Int J Biodivers Conserv. 2012:4(3):101-12.
35. Barbuti RC. Diarreias agudas: Aspectos clínicos, etiológicos e terapêuticos. Rev Brasil Med. 2008:34(1):3-12.

36. Santos RFEP, Silva I, Veríssimo R, Lúcio I, Campesatto E, Conserva L, Bastos M. Estudo do potencial antimicrobiano e citotóxico da espécie Pouteria venosa (Sapotaceae). Rev Bras Plantas Med. 2015;17(3):367-73.

37. Lopez KSE. Estudo químico e atividade biológica de Pouteria torta (Mart.) Raldk (Sapotaceae). Dissertação de Mestrado, Universidade de Brasília, Brasília. 2005, 197p

38. Alves TMA, Silva AF, Brandão M, Grandi TS, Smania EFA, Junior AS, Zani CL. Biological screening of brazilian medicinal plants. Mem Inst Oswaldo Cruz. 2000;95(3):367-73

39. Silva CA de M. Contribuição ao estudo químico e biológico de Pouteria gardneri (Mart \& Miq.) Baehni (Sapotaceae). Dissertação Mestrado de Ciências da Saúde, Universidade de Brasília, Brasília, 2007, 173p. Available from: http:// repositorio.unb.br/handle/10482/3379

40. Humason AW. A search for multi-drug resistance pump inhibitor molecules by isolation of natural products. Master of Science Dissertation with a Major in Chemistry, Faculty of Dedman College Southern Methodist University, Dallas, Texas, 2004, 75p. Available from: https://search.proquest.com/openview/e373 3e7f3702ac5ad771 fe576e4d225e/1 ?pq-origsite = gscholar\&cbl=18750\&diss=y

41. Agripino DG, Lima MEL, Silva MR, Meda Cl, Bolzani VS, Cordeiro I, et al. Screening of brazilian plants for antimicrobial and DNA damaging activities. Biota Neotrop. 2004;4(2):1-15.

42. Evangelista ACS. Pouteria caimito (Ruiz \& Pav.) Radlk: um novo potencial terapêutico? Dissertação (Trabalho de Conclusão de Curso) - Faculdade de Farmácia, Universidade Federal de Juiz de Fora, Juiz de Fora, Minas Gerais, 2017, 72p.

43. Fabry W, Okemo PO, Ansorg R. Antibacterial activity of East African medicinal plants. J Ethnopharmacol. 1998;60(1):79-84

\section{GRAPHICAL ABSTRACT}

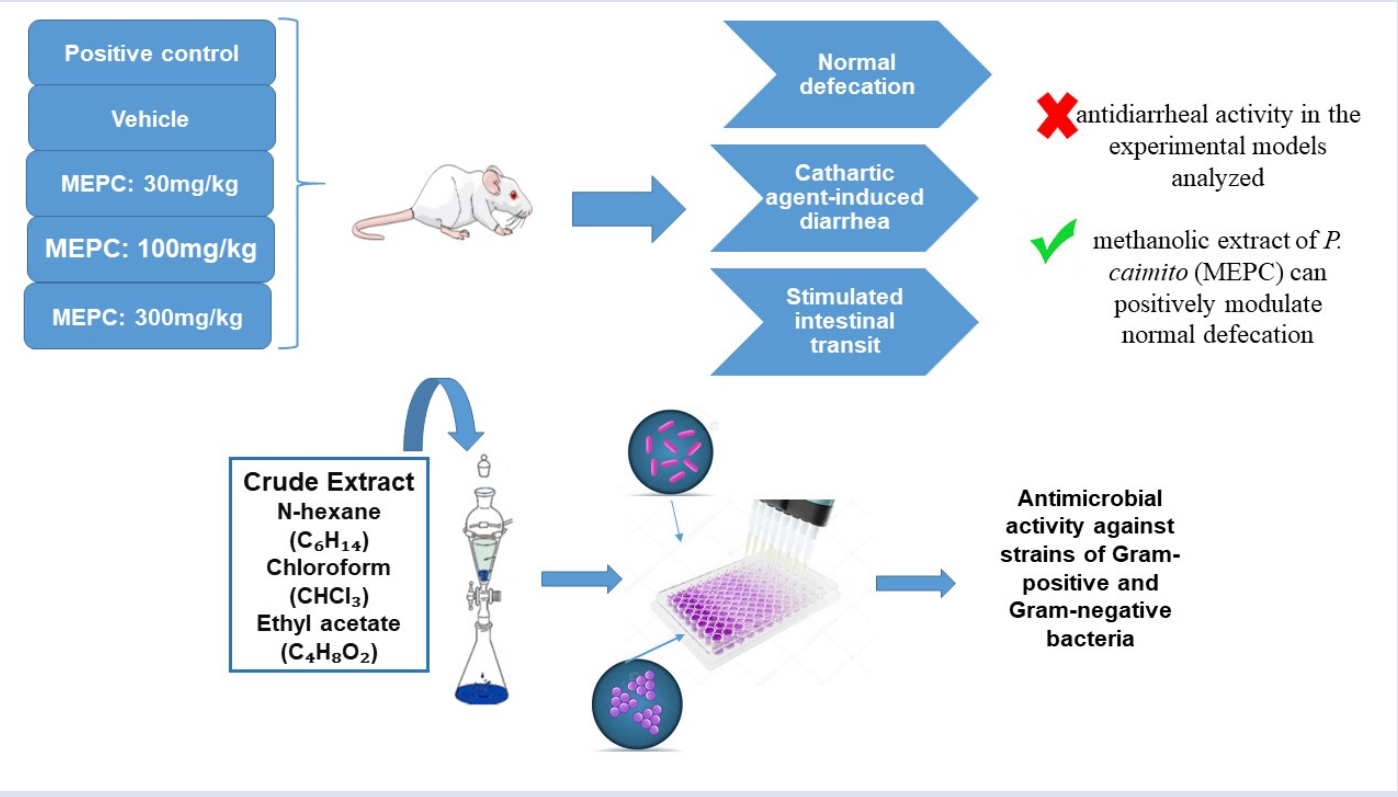

\section{ABOUT AUTHORS}

Marina Medeiros De Abreu: Dietitian, graduated from the State University of Ceará, a postgraduate degree in Clinical Nutrition from Gama Filho University and master's degree from the Federal University of Amapá. He is currently a dietitian at "Mae Luzia" Maternity Hospital.

Alessandra Azevedo Do Nascimento: Graduated in Pharmacy (1997), Qualification in Clinical Analysis by the Federal University of Paraíba (1999), Master's (2001) and Doctor's degree (2008) in Pharmacology of natural and synthetic bioactive products by Federal University of Paraíba (UFPB) - Laboratory of Pharmaceutical Technology. Currently an Associate Professor at the Federal University of Amapá and Coordinator of the Postgraduate Program in Health Sciences (PPGCS / UNIFAP). Experience in the field of Pharmacy, with an emphasis in Clinical Pharmacy and Preclinical Pharmacology. 
Fábio Rodrigues De Oliveira: Pharmacist - Biochemist (2010) by the Federal University of Pará, Professor, and researcher at the Federal University of Amapá, with a Ph.D. in progress (Neuroscience area) at the Federal University of Pará.

Priscila Faimann Sales: Master student of the Health Sciences course of the Federal University of Amapá (UNIFAP). Bachelor in Biomedicine with Qualification in Clinical Analyzes by Estácio University/Macapá (2016). Trainee at the Laboratory of Natural Products and Genetic Parameters of the Institute of Scientific and Technological Research of the State of Amapá-IEPA and in the Laboratory of Botany of the Institute of Scientific and Technological Research of the State of Amapá -IEPA.

Patrícia De Almeida Nóbrega: Master in Health Sciences (PPGCS) from the Federal University of Amapá, a postgraduate degree in Teaching Higher Education by META College / Macapá - Amapá (2015), graduation in Chemistry from the State University of Paraíba (2007).

Cite this article: Abreu MM, Nobrega P De A, Sales PF, Oliveira FRDe, Nascimento AA. Antimicrobial and Antidiarrheal Activities of Methanolic Fruit Peel Extract of Pouteria caimito. Pharmacog J. 2019;11(5):944-50. 